DOI: 10.20472/IAC.2018.044.024

\title{
MOUNA KOHIL
}

Ecole Supérieure des Technologies Industrielles-Annaba, Algeria

\section{'MAN IS NOT TRULY ONE, BUT TRULY TWO': DUALITY IN STRANGE CASE OF DR JEKYLL AND MR HYDE}

\begin{abstract}
:
The present works aims at exploring the Strange Case of Dr Jekyll and Mr Hyde by the Scottish author Robert Louis Stevenson in the light of the theme of duality. It provides an understanding on the issue of restraining and repressing one's lower side due the constraints of decency, which may lead to creation of another character which acts as an escape tool from these restraints. The work analyzes the various aspects of duality by exposing Dr Jekyll's contradictions and his wild tendencies. It explains how the respectable doctor resorted to a magical potion in order to create an outlet for his wild self. Mr Hyde, who represents Dr Jekyll's double, is portrayed as a monstrous villain which terrorizes the Victorian society. In his novella, Stevenson warns from the unethical use of knowledge and the horrors of holding back human natural instincts.
\end{abstract}

\section{Keywords:}

duality, the double, Dr Jekyll, Mr Hyde, repression 


\section{Introduction}

The shift from the Romantic Age to the Victorian Age paved the way for new social perception. The mass concern about external looks and etiquette was dominant, not only at the level of the Victorian community and its conformist outfit, but also at the level of literature. Nevertheless, people harbour vices, it is ultimately improper to conform to these vices and perform them publically. Consequently, literature of the era concentrated on the effects of concealing what is underneath the surface. During a time when the interest in the human psyche grew considerably, Robert Louis Stevenson, in Strange Case of Dr Jekyll and Mr Hyde, translates the horrors resulting from repressing one's desires and lower side. Therefore, it is paramount to examine the consequences of conducting a double life and holding back the human instincts that may be thought out as improper in a society that prefers preserving a conservative fascia.

In Strange Case of Dr Jekyll and Mr Hyde, Stevenson projects the double theme onto the figure of Mr Hyde. According to Linehan, it is probably Stevenson's troubling ideas about the double nature of humans that leads him to the creation of a frightening story that could be understood as "a horror thriller about human duality which shows the relentless supplanting of the most presentable side of self by the most unpresentable one, the tale exhibits a remarkable ability to hit a nerve and produce a shock of recognition for generation after generation of readers" (Katherine, Linehan, 2003)i. The double or the doppelgänger refers to a character in the story which has a duplicate similar in form but distinct in intentions. Doppelgänger of the main character is able of impersonating the original but have vastly different spirits and attitudes. The doubling displays characters that are not able to identify themselves as individuals. The motif of the double has connections with "'mirrors, with shadows, guardian spirits, with the belief in the soul and the fear of death,' and often represents a division of the self"(Sigmund, Freud, 2004)".

Several times in the story, Dr Jekyll hints about the enjoyments he used to indulge in his youth, and how he was obliged to hold back his natural instincts in order to maintain his position in society as the respectable man of science. However, when he succeeds in separating his both sides, Jekyll creates a vehicle via which he is able to obey his instincts without tarnishing his social image. Still, the main issue facing $\mathrm{Dr}$ Jekyll is that there is no cleaving point between where one self starts to appear, and where the other disappears since they are sides of the same person. However, Dr Jekyll does not try to assimilate both selves into one, but, rather, he opts to separate them.

From the onset of the story, and until Jekyll's first person confession, the life of Jekyll is described as secretive and wild. As a result, his pleasures had to be repressed and hidden from the public eye. As Linehan posits: "the text turns out always to hover around, never to reveal, the specific pleasures that Jekyll is eager to pursue" (xii). Thus Jekyll keeps his repressed desires ambiguous. Jekyll's allusion to his past indicates that the life 
he conducted is inappropriate, and did not suit the public expectations; therefore, he had to repress his lower self. As he declares:

And indeed the worst of my faults was a certain impatient gaiety of disposition, such as has made the happiness of many, but such as I found it hard to reconcile with my imperious desire to carry my head high, and wear a more commonly grave countenance before the public (Robert Louis, Stevenson, 2006) iii. $^{\text {ii. }}$

Even though gaiety is not a transgression to any law, it may have stirred the superfluous attention of people, who see it as unfitting to the Victorian decorum. This is evident in Dr Lanyon's negative statement on Jekyll's past: "But it is more than ten years since Henry Jekyll became too fanciful to me" (12). In addition, Mr Utterson, the lawyer, asserts that Dr Jekyll's latest absence is perhaps due to his old sins:

He was wild when he was young; a long while ago to be sure; but in the law of God, there is no statute of limitations. Ay, it must be that; the ghost of some old sin, the cancer of some concealed disgrace: punishment coming, pede claudo, years after memory has forgotten and self-love condoned the fault (17).

However, it is probable that both characters overstate Jekyll's past because they considered his manners wild. Thus, they tend to distance themselves from him. In addition, and more probably, Dr Jekyll's confession about what made his past turn wild is not entirely credible. Consequently, Jekyll attempts to separate himself from Hyde and places him in a shabby and filthy street in London away from his house in the upper class West Central London.

In his confession, Dr Jekyll declares that he suffers from the burden of his dishonourable past. Moreover, the attempt to hold back his wilder side begets a feeling of duality. Dr Jekyll speaks of how he feels the existence of two persons within him: one who represents the respectable doctor and the other, who symbolises the lower-animal instincts of his past. He asserts: "Hence it came about that I concealed my pleasures; and that when I reached years of reflection, and began to look round me and take stock of my progress and position in the world, I stood already committed to a profound duplicity of life" (52). In this statement, Jekyll realises his "doubleness", and tries to define this duplicity, and, therefore, he constructs a case study. Anne Stiles refers to Dr Jekyll's attempt to understand duality as an endeavour to: "explore the potentially heretical possibility that human beings are inherently double even in a healthy state" (Anne, Stiles, 2006) $)^{\text {iv }}$. Regarding what Stiles claims, this doubling is not essentially negative when the person in question attempts for integration. It is worth noting that Jekyll's aim is to detach his two selves and not to assimilate them.

Strange Case of $\mathrm{Dr}$ Jekyll and Mr Hyde attempts to portray Jekyll's duality in a conservative ethical language, and in accordance with the Victorian mode. Dr Jekyll uses such language in order to explain his duality. he says: "It was thus rather the exacting 
nature of my aspirations than any particular degradation in my faults, (that made me what I was and, with even a deeper trench than in the majority of men, severed in me those provinces of good and ill which divide and compound man's dual nature" (52). Moreover, in addition to Jekyll's recognition of his duality, his ultimate goal is to split his both sides. He declares: "It was the curse of mankind that these incongruous faggots were thus bound together that in the agonised womb of consciousness, these polar twins should be continuously struggling. How, then, were they dissociated?" (53) Robert Rogers claims that Jekyll's doppelgänger does not symbolise duality, but a division of his persona, associated with "the more dramatic phenomenon of dissociation, known better by its result, the dual or multiple personality"(Robert, Rogers, 1970)v.

While Dr Jekyll's wild past remains ambiguous, it becomes apparent that his past adventures are more than improper to the public. Jekyll states that: "Men have before hired bravos to transact their crimes, while their own person and reputation sat under shelter. I was the first that ever did so for his pleasures" (Stevenson, 2006: 56). According to this, Jekyll's past deeds can be understood as crimes. In addition, Jekyll confesses that he concealed the wild part of his personality in order to maintain the Victorian decorum. Barbara D'Amato maintains that Hyde's actions "embrace the notion of duality in man and the presence of unconscious impulses" (Barbara, D'Amato, 2005) vi. It is clear that Dr Jekyll is aware of Mr Hyde's deeds, even if he is helpless in holding him back.

Interestingly, it should have been quite frightening for Jekyll to realise the evil nature of his double. However, at certain moments, it seems that he is excited. As he asserts: "I knew myself, at the first breath of this new life, to be more wicked, tenfold more wicked, sold a slave to my original evil; and the thought, in that moment, braced and delighted me like wine" (Stevenson, 2006: 54). In the light of this, the glee that Jekyll feels surpasses the feeling of freedom he enjoys as being Hyde, but further, it represents his enjoyment in taking revenge on the rigid Victorian system that obliges him to repress his instincts. Therefore, Jekyll considers his conversion, close to his colleagues, to be exciting and somehow amusing: "I had but to drink the cup, to doff at once the body of the noted professor, and to assume, like a thick cloak, that of Edward Hyde. I smiled at the notion; it seemed to me at the time to be humorous; and I made my preparations with the most studious care" (56). Thus, Jekyll's initial enjoyment with his transformation is undeniable, and it is only when Hyde takes control over him that he realises his fault.

Interestingly, Edward Hyde is the personification of Jekyll's denied desires. This is why he symbolises not only his unconscious part, but further his natural and primitive aspects. Unsurprisingly, Mr Hyde is different from Dr Jekyll; he is smaller and younger than Jekyll. From a psychological stand point, and as Anne Stiles suggests, this decrease in stature is due to the fact that Hyde, as a part of Jekyll, is improperly utilised: "the persona embodying Jekyll's 'evil side' is smaller and less robust because it is under-used; Hyde represents the atrophied, stunted right hemisphere struggling to break free of the 
restraints imposed by the dominant left brain" (Stiles, 2006: 886). In addition, Edward Hyde is, frequently, depicted as an animal-like creature resembling the ape. As Poole, the servant exclaims: "when that masked thing like a monkey jumped from among the chemicals and whipped into the cabinet, it went down my spine like ice" (Stevenson, 2006: 39). Similarly, Dr Jekyll notices: "Hence the apelike tricks that he would play me, scrawling in my own hand blasphemies on the pages of my books, burning the letters and destroying the portrait of my father; and indeed, had it not been for his fear of death, he would long ago have ruined himself in order to involve me in the ruin" (65). In addition, the apprehension of characters regarding Hyde's ape-like figure reflects the Victorian concern with Charles Darwin's theory of evolution.

Regarding Hyde's evil tricks, as confessed by Jekyll, it is paramount to consider that the latter continuously detaches himself from his opposite, and denies his responsibility toward his wicked deeds. However, as stated by the clerk in the story, the hand writing of Jekyll and Hyde has "a singular resemblance; the two hands are in many points identical; only differently sloped" (27). It is worth noting that Jekyll declares that Hyde wrote using his own hand, thus, implying, unconsciously, that he is not separate from his opposite.

In addition, the fact that Hyde destroys the letters and the portrait of Jekyll's father implies that $\mathrm{Dr}$ Jekyll, via his double, expels his negative repressed emotions toward his father. Robert Rogers claims that Hyde's murder of Mr Carew is due to Jekyll's repression of his feelings. He writes:

Both Jekyll and Hyde exhibit a Faustian rebelliousness, Jekyll in his chemical experiments and Hyde in scrawling blasphemies in the margins of pious books and in destroying the letters and portrait of Jekyll's father. The destruction of the portrait seems to tie in with what looks like a patricide motif in the otherwise unexplained murder of Carew by Hyde (Rogers, 1970: 94).

Even though there is no clear direct hint related to Jekyll's suppressed hatred toward his father, it is worth mentioning that Jekyll was, potentially, under a pressure of his father to conform to the same principle of conservatism in their society. In the light of this, the question whether Jekyll's father influenced his son's professional decisions remains open. It is quite palpable that it is not Jekyll's choice to maintain such restricting life style, which leads to the creation of a double figure which allows him to indulge himself on what is pleasurable for him, but considered improper by the rules of his society.

It is worth noting that the consideration of Hyde as a physical embodiment of Jekyll's repressed desire elucidates the reason why people who encounter Hyde find it difficult to explain his appearance. Poole says: "Then you must know as well as the rest of us that there was something queer about that gentleman - something that gave a man a turn - I don't know rightly how to say it, sir, beyond this: that you felt it in your marrow kind of cold and thin" (Stevenson, 2006: 39). Similarly, Jekyll says: 
I have observed that when I wore the semblance of Edward Hyde, none could come near me at first without a visible misgiving of the flesh. This, as I take it, was because all human beings, as we meet them, are commingled out of good and evil: and Edward Hyde, alone in the ranks of mankind, was pure evil (55).

Following this, people's reaction when they look at Hyde, as Dr Jekyll notes, is due to Hyde's wickedness. Moreover, when people meet Hyde, they feel nervous. The fact that Hyde is difficult to describe is illustrated when Mr Enfield comments. He says: "He [Hyde] is not easy to describe. There is something wrong with his appearance; something displeasing, something downright detestable. I never saw a man I so disliked, and yet I scarce know why" (9). Therefore, the characters's reaction when they meet Hyde is linked to the fact that he represents their repressed unconscious. Freud suggests that if the repressed elements, which occur in the unconscious, "hidden away"( Freud, 2004: 421), reappear in consciousness, they result in an uncanny feeling.

Seemingly, the expression of the uncanny is achieved through the double. Therefore, characters' reaction to Hyde is due to the fact that he represents what is hidden in the unconsciousness and ought to "remain secret" (Freud, 2004: 429). Besides, the fact that they could not provide a clear description for Hyde implies that they, also, repress their instincts, but do not allow them to turn into their conscious.

Despite Hyde's crimes, and because he offers freedom for Jekyll's inner desires, the latter, repeatedly, implies that Hyde is a kind of "familiar that I called out of my own soul, and sent forth alone to do his good pleasure" (Stevenson, 2006: 57). This urge for freedom leaves Jekyll unaware of the force that his double is gaining, and, instead, he believes that he is still in control. He declares: "I will tell you one thing: the moment I choose, I can be rid of Mr Hyde" (19). Despite the fact that Jekyll realises that he cannot permit himself to live a double life, he is found hesitating between the two personas, because to get rid of Hyde means that he will put an end to his pleasures. He confesses: "To cast in my lot with Jekyll, was to die to those appetites which I had long secretly indulged and had of late begun to pamper" (59).

Interestingly, the reason why Jekyll chooses his persona over that of Hyde is due to the public doubtfulness regarding his behaviour: "I cannot say that I care what becomes of Hyde; I am quite done with him. I was thinking of my own character, which this hateful business has rather exposed" (25). However, Jekyll, eventually, realises that his choice in getting rid of Hyde is not well studied: "I made this choice perhaps with some unconscious reservation, for I neither gave up the house in Soho, nor destroyed the clothes of Edward Hyde, which still lay ready in my cabinet" (60). It is paramount to consider Jekyll's late recognition of Hyde's autonomous nature that gained control over his self. Therefore, Hyde is more powerful than Jekyll which is another reason as to why the latter chooses to end his double: 
I began to reflect more seriously than ever before on the issues and possibilities of my double existence ... and I began to spy a danger that, if this were much prolonged, the balance of my nature might be permanently overthrown, the power of voluntary change be forfeited, and the character of Edward Hyde become irrevocably mine (59).

In the light of this, Jekyll becomes aware of the dangers of Hyde's increased control. Even though he, involuntarily, confesses that Hyde is a part of him. He attributes all the crimes to Hyde, thus, contradicting himself and suggesting that he is a separate character: "The pleasures which I made haste to seek in my disguise were as I have said, undignified; I would scarce use a harder term. But in the hands of Edward Hyde, they soon began to turn towards the monstrous" (57). By doing so, Jekyll projects his monstrosity against his double. When Hyde kills Mr Carew, he says that: "the spirit of hell awoke in me and raged. With a transport of glee, I mauled the unresisting body, tasting delight from every blow; and it was not till weariness had begun to succeed, that I was suddenly, in the top fit of my delirium, struck through the heart by a cold thrill of terror" (60-61).

Unsurprisingly, when Dr Jekyll realises that he is about to lose control, he commits his greatest mistake: he tries to get rid of his evil side completely, instead of incorporating both in one persona. Till this point, Hyde is considered as an autonomous person, and Jekyll holds no responsibility toward his deeds. Therefore, Jekyll, no more, considers Hyde as a disguise through which he enjoys his denied pleasure: "He, I say - I cannot say, I" (63). Initially, Dr Jekyll creates Hyde for fear of public judgment; however, after the death of Mr Carew, he fears his transformation into his evil part more. He confesses: "A change had come over me. It was no longer the fear of the gallows, it was the horror of being Hyde that racked me" (64). For D'Amato, the liberty that Jekyll enjoys through Hyde is what makes Hyde stronger, because when "Hyde kills, he becomes stronger. Tasting murder, Dr. Jekyll finds it more difficult to contain Mr. Hyde. Multiple doses of the draught become necessary for Jekyll to resurface" (D'Amato, 2005: 101). Eventually, Jekyll realises the dangers of his double and decides to end the life of Hyde. It is worth noting that with the end of Hyde, Dr Jekyll will no longer live. As he declares in his confession: "here then, as I lay down the pen and proceed to seal up my confession, I bring the life of that unhappy Henry Jekyll to an end" (Stevenson, 2006: 66). Moreover, when the body of Hyde is discovered, instead of Jekyll's, it becomes possible to think that it is Hyde, who committed suicide. However, according to Jekyll's final confession, it is logical to declare that it is Jekyll who ends up the life of both personas. Thus, the dual life of Dr Jekyll ends with the death of his double.

In Strange Case of Dr Jekyll and Mr Hyde, Henry Jekyll represents a separated self. For both Carl Jung and Sigmund Freud, it is not impossible to handle such a division. For Jung, in the process of assimilating both selves, the most difficult part is confronting the double: "The meeting with oneself is, at first, the meeting with one's own shadow. The 
shadow is a tight passage, a narrow door, whose painful constriction no one is spared who goes down to the deep well" (Carl Gustave, Jung, 1968)vii. Once the person confronts his dark half, and assumes his responsibility toward him, the process of assimilation into a consistent self becomes possible. Equally, Sigmund Freud sees the assimilation process as possible but he offers no clear resolution; rather, he considers the double as a part of the unknown or the uncanny.

It is paramount to state that Henry Jekyll fails to assimilate his split parts because he refuses to take responsibility of his other half. Moreover, he denies his connection with his double. Such rejection is boosted by the concerns of his community and the Victorian principles regarding religion and morality. By highlighting the regressive nature of Hyde, Jekyll justifies his aim of getting rid of him. Thus, Jekyll tries to preserve the self that fits society best, but ends up by destroying both selves illustrating that the human psyche could never be divided into 'good' or 'evil'.

In Strange Case of Dr Jekyll and Mr Hyde, R. L. Stevenson, skillfully, captures the contradictions of the Victorian society. The novella warns from the negative consequences of burying the natural (animal) instincts of man underneath the confining ideas of decency. Stevenson offers a horrific insight into the dark corners of the human nature.

\section{References}

Linehan, Katherine (2003). "Preface", Strange Case of Dr. Jekyll and Mr. Hyde. By Robert Louis Stevenson 1886, Ed. Linehan. New York, and London: W.W. Norton \& Company, Inc., 2003, xii.

Freud, Sigmund (2004). "The Uncanny", Literary Theory: An Anthology, Eds. Julie Rivkin and Michael Ryan. Blackwell Publishing Ltd., 2004, 425.

Stevenson, Robert Louis (2006). Strange Case of Dr Jekyll and Mr Hyde and Other Tales, Ed. Roger Luckhurst. Oxford: Oxford University Press, 2006, 52.

Stiles, Anne (2006). Robert Louis Stevenson's Jekyll and Hyde and the Double Brain. SEL: Studies in English Literature 1500-1900. 2006, Vol. 46, No.4, 855.

Rogers, Robert (1970). A Psychoanalytic Study of the Double in Literature, Ed. Rogers. Detroit, Ml: Wayne State University Press, 1970,15.

D'Amato, Barbara (2005). Jekyll and Hyde: A Literary Forerunner to Freud's Discovery of the Unconscious. Modern Psychoanalysis. 2005, Vol.30, No.1, 93.

Jung, Carl Gustav (1968). "Archetypes of the Collective Unconscious", The Archetypes and the Collective Unconscious, Trans. R.F.C. Hull, Eds. Sir Herbert Read, and Michael Fordham, et al. Bollinger Series XX, $2^{\text {nd }}$ Ed. New York: Princeton University Press, 1968, 21. 